\title{
Experimental Application of Sage in Rabbit Husbandry
}

\author{
R. SZABÓOVÁ ${ }^{1}$, A. LAUKOVÁ ${ }^{1}$, L. CHRASTINOVÁ ${ }^{2}$, M. SIMONOVÁ ${ }^{1}$, \\ V. STROMPFOVÁ ${ }^{1}$, M. HAVIAROVÁ ${ }^{1}$, I. PLACHÁ ${ }^{1}, \check{S}^{\prime}$. FAIX ${ }^{1}$, Z. VASILKOVÁ $^{3}$, \\ M. CHRENKOVÁ2 ${ }^{2}$ J. RAFAY ${ }^{2}$ \\ ${ }^{1}$ Institute of Animal Physiology, Slovak Academy of Sciences, Košice, Slovakia \\ ${ }^{2}$ Slovak Centre of Agricultural Research, Nitra, Slovakia \\ ${ }^{3}$ Parasitological Institute, Slovak Academy of Sciences, Košice, Slovakia \\ Received January 17, 2008 \\ Accepted June 11, 2008
}

\begin{abstract}
Szabóová R., A. Lauková, L. Chrastinová, M. Simonová, V. Strompfová, M. Haviarová, I. Plachá, Š. Faix, Z. Vasilková, M. Chrenková, J. Rafay: Experimental Application of Sage in Rabbit Husbandry. Acta Vet. Brno 2008, 77: 581-588.

Salvia spp. belongs to the Labiatae family and is characterized by antimicrobial and antiinflammatory effect. The aim of this study was to test its in vitro and in vivo inhibitory effect against bacteria as well as to find an alternative possibility to use sage in the rabbit ecosystem examining biochemical, zootechnical and inmunological indicators, compared to the commercial feed mixture Xtract. Using the sage extract in in vitro tests, its inhibitory effect was noted. Under in vivo conditions, in the experimental group with sage (EG1), reduction of Pseudomonas-like sp. $(p<0.01)$ and E. coli $(p<0.01)$ was noted after 7 days of sage application compared to the control group CG2 (with Robenidin) as well as after 21 days of sage extract application, when the reduction of coagulase-negative staphylococci $(p<0.01)$ was detected (in comparison with the experimental group-EG2, Xtract group). In the caecum of rabbits from EG1, higher values of lactic, acetic and butyric acids were noted. The values of propionic acid were not influenced. Biochemical indicators were not influenced; however, the values of GSH Px were lower in EG1 compared to EG2. Higher phagocytic activity (18\%) was noted in EG1 than in EG2 (13\%) after 21 days of additives application. The reduction of Eimeria sp. oocysts was demonstrated in EG1 (sage group) after 7 days of sage application comparing to CG2 (217 OPG to 566 OPG). The animals in both experimental groups achieved higher feed consumption and weight gain, lower mortality compared to both controls. Neither of the additives had a negative influence on the health status and growth performance of rabbits.
\end{abstract}

Salvia officinalis, Oryctolagus cuniculus, in vitro, in vivo, effect, activity

The development of intensive rabbit husbandry is concerned with biological properties of rabbits such as fertility, fast growth and wholesome rabbit meat. The maintenance of healthy breeding as well as quality of feeds is a prerequisite for successful production of rabbit meat. However, enteric diseases frequently occur in rabbits around the weaning period leading to an extensive use of antibiotics. It is generally known, that the use of antibiotics as feed additives was banned by the European Union (EU) by 1. 1. 2006. Therefore new and safe antimicrobial agents are searched to prevent and/or overcome bacterial, viral and fungal infections. The use of phytoadditives and their extracts in rabbit husbandry offers an acceptable way to improve welfare, health and meat quality of rabbits (Xu et al. 1999; Szabóová et al. 2006; Fichi et al. 2007). There are several alternative approaches with no use of antibiotics for the maintenance of microflora balance in the gastro-intestinal tract, such as the use of acidificators, probiotics, prebiotics and enzymes. The use of secondary metabolites of plants containing essential oils with inhibitory effects against pathogens also represents an alternative approach (Marcin et al. 2006).

Phytoprevention and phytotherapy (using plants, herbs) is ancient and has become popular. Medicinal herbs are very commonly used in Asia but they are also widely consumed all over the world (Basgel and Erdemoglu 2006). The genus Salvia (sage) encompasses about

Address for correspondence:

MVDr. Andrea Lauková PhD

Institute of Animal Physiology

Slovak Academy of Science

Šoltésovej 4 - 6, 04001 Košice

Slovakia

Phone: +421-55-6330283

Fax: +421-55-7287842

E-mail: laukova@saske.sk

http://www.vfu.cz/acta-vet/actavet.htm 
900 species of plants belonging to the mint family Lamiaceae (Labiatae, Gali-Muhtasib et al. 2000). Many Salvia spp. are used as herbal tea and for food flavouring, as well as in cosmetics, perfumeries and in the pharmaceutical industry (Karakaya et al. 1999; Tepe et al. 2006). Salvia officinalis L. is a common aromatic and medicinal plant native to Mediterranean countries; there it is in widespread use (Lima et al. 2005). Different types of extracts of Salvia officinalis possessed antioxidant, anti-inflammatory, hypoglycaemic and anti-mutagenic bioactivities (Wang et al. 1998; Baricevic et al. 2001; Alarcorn-Aquilar et al. 2002). The ethanolic tinctures and decoctions of sage (Salvia officinalis L.) have long been known for their effects in various inflammations of oral cavity, digestive and intestinal tracts, in gastritis and tonsilitis (Capek et al. 2003). Rabbit ecosystem represents a new possibility of studying the effects of Salvia officinalis and comparing it with commercial feed mixture Xtract (involving carvacrol, capsaicine, cinnamaldehyde).

\section{Materials and Methods}

Schedule of in vivo experiment

Eighty-eight rabbits (35-days old, male sex, Hy-plus hybrid) were divided into 2 experimental (EG1, EG2) and 2 control groups (CG1-standard and CG2 with coccidiostat Robenidin, $66 \mathrm{mg}$ per $\mathrm{kg}$ of feed during 2 weeks) of 22 rabbits in each. The experiment was performed on the farm (Slovak Centre of Agricultural Research in Nitra). All care and experimental procedures involving animals followed the European Community guidelines (EEC Directive-86/609) with approval of the Slovak Governmental Veterinary Office. The animals in the experimental group EG1 received the sage extract in drinking water (a dose $10 \mu \mathrm{l}$ for animal per day developed on in vitro tests; that is $220 \mu \mathrm{l}$ for group of 22 animals per day). The volume of water commonly drunk by rabbits in the housing system is known. Feed for rabbits in EG2 was supplemented by Xtract (15 g/100 kg feed, Cymedica SK s.r.o., Zvolen, Slovakia) as is commonly fed. Sage and Xtract were administered from the start of the experiment in the duration of 21 days. Moreover, all animals fed the commercial diet for growing rabbits (ANPRO.FEED, VKZ Bučany, Slovakia) with access to water ad libitum. The experiment (samples checking) was performed for 6 weeks (age of rabbits at the end of the experiment 77 days).

In vitro and in vivo microbiological analysis

In vitro the inhibitory activity of sage extract (Salvia officinalis extract contained $24 \%$ of thujone, $18 \%$ of borneol, 15\% of cineole; Calendula a.s., Nová Lubovňa, Slovakia) was tested by the agar spot test according to DeVuyst et al. (1996) against the target of indicator bacteria from different ecosystems (faeces and caecum of rabbits, faeces of turkeys and rodents, silage, fermented meat products and strains from the collection, CCM - syn. Czech Collection of Microorganisms, Table 1).

Samples of faeces during in vivo experiment were taken at the beginning of the experiment (age of rabbits 35 days), after 7 days of additive administration (age of rabbits 42 days), after 21 days of additive administration (age of rabbits 56 days) and 21 days after additive withdrawal (age of animals 77 days) to monitor the counts of selected bacterial groups. Fecal samples were treated by a standard microbiological method using appropriate dilutions in Ringer solution ( $\mathrm{pH}$ 7.0; Oxoid Ltd., Basingstoke, Hampshire, England). The appropriate dilutions were plated onto M-Enterococcus agar, Mannitol Salt Agar (Difco Laboratories, Detroit, USA) and Clostridium difficile agar with selective supplement (SR0096E) and 7\% (v/v) defibrinated horse blood (SR0050; Oxoid Ltd., Basingstoke, Hampshire, England) to enumerate enterococci, coagulase-negative staphylococci (CNS) and Clostridium-like sp. Cetrimide agar and Mac Conkey agar (Becton \& Dickinson) were used to count E. coli and Pseudomonas sp. The plates were incubated at $37{ }^{\circ} \mathrm{C}$ (for Pseudomonas laboratory temperature) for $24-48 \mathrm{~h}$ depending on the bacterial species. Moreover, three animals of each group were slaughtered after 21 days of additive administration and 21 days after additive withdrawal; caecal samples were serially diluted in Ringer solution ( $\mathrm{pH}$ 7.0; Oxoid Ltd., Basingstoke, Hampshire, England) and plated on the media former mentioned. The count of enterococci, CNS, Pseudomonas-like sp., Clostridium-like sp. and E. coli in rabbit faeces and caecum were expressed as $\log 10$ of colony forming units (CFU/g) per gram. The results are quoted as mean $\pm \mathrm{SD}$ (standard deviation).

Biochemical analysis, phagocytic activity and zootechnical indicators

Blood samples were taken at the start of the experiment (day $0-1$, age of rabbits 35 days), after 21 days of additive administration (age of rabbits 56 days), at the end of the experiment, and 21 days after additive withdrawal (age of rabbits 77 days). The following analyses were provided: serum concentrations of total proteins and lipids $(\mathrm{g} / \mathrm{l})$, cholesterol, glucose, calcium $(\mathrm{mmol} / \mathrm{l})$, alanine aminotransferase $(\mu \mathrm{kal} / \mathrm{l})$ and gluthatione peroxidase (GSH $\mathrm{Px}, \mathrm{U} / \mathrm{g} \mathrm{Hb}$ ) using the commercial kit, Randox (Crumlin, England) GSH Px was tested according to Paglia and Valentine (1967). Haemoglobin was also tested using the commercial kit Randox. Moreover, phagocytic activity and index of phagocytic activity were tested and expressed in \%; that is, the approach of phagocyting cells (ingested at least one particuls-yeasts) to 100 neutrophils. Index of phagocytic activity indicates the attitude of phagocyting particles count to phagocyting cells counts (Hrubiško 1981). Volatile fatty acid values were determined using gas chromatography from the caecal content. The zootechnical indicators (feed consumption, 
weight gain, feed conversion, mortality) were evaluated daily. The statistical evaluation of the results was performed by the one-way ANOVA post-Tukey test.

Eimeria sp. oocysts detection

Eimeria sp. oocysts were observed in faecal samples microscopically at the start of the experiment (age of rabbits 35 days), after 7 days of additive administration (age of rabbits 42 days), after 21 days of additive administration (age of rabbits 56 days) and after cessation of additive administration. The samples were stored at $4{ }^{\circ} \mathrm{C}$ and then evaluated by the quantitative flotation technique - McMaster Method (Ministry of Agriculture, Fischeries and Food, UK, 1986). The intensity of the infections was determined in counts of oocysts per $1 \mathrm{~g}$ of faeces - OPG.

\section{Results}

Among 35 strains of Clostridium-like sp., the growth of 27 strains was inhibited by the sage extract (77.0\%, Table 1). Among 16 staphylococci, the growth of 9 strains was inhibited $(56.0 \%)$ and among 66 strains of Pseudomonas-like sp. 41 were inhibited (62\%).

Table 1 . Inhibitory activity of sage extract against the target of indicator bacteria

\begin{tabular}{|c|c|c|}
\hline & \multicolumn{2}{|c|}{ Sage } \\
\hline & $\begin{array}{c}\text { Tested/inhibited } \\
\text { strain }\end{array}$ & $\%$ \\
\hline Enterococcus sp. & $58 / 9$ & 16 \\
\hline Lactobacillus sp. & $13 / 2$ & 15 \\
\hline Staphylococcus sp. & $16 / 9$ & 56 \\
\hline Listeria monocytogenes CCM 4699 & $1 / 0$ & 0 \\
\hline Listeria monocytogenes LM 6, LM 7, LM 8, LM 9 & $4 / 0$ & 0 \\
\hline Listeria innocua LMG 13568 & $1 / 0$ & 0 \\
\hline Aerococcus viridans & $5 / 0$ & 0 \\
\hline Clostridium-like sp. & $35 / 27$ & 77 \\
\hline Pseudomonas-like sp. & $66 / 41$ & 62 \\
\hline E. coli & $90 / 20$ & 22 \\
\hline Salmonella enterica serovar Düsseldorf SA $31^{*}$ & $1 / 0$ & 0 \\
\hline Salmonella enterica serovar Enteritidis PT4** & $1 / 0$ & 0 \\
\hline Salmonella enterica serovar Typhimurium*** & $1 / 0$ & 0 \\
\hline
\end{tabular}

*The strain was supplied by Dr. Vasilková, Parasitological Institute, SAS, Košice, Slovakia

*** The strain was kindly supplied by Dr. Šišák, Brno, Czech Republic

**** The strain was kindly supplied by prof. Marounek and Dr. Škardová, Prague, Czech republic

In faecal samples of rabbits in EG1 group, the reduction of Pseudomonas-like sp. $(p<0.01)$ and $E$. coli $(\mathrm{CFU} / \mathrm{g} ; p<0.01)$ was observed after 7 days of sage extract administration in comparison to CG2 and CG1 as well as after 21 days of sage extract application when the reduction of CNS $(p<0.01)$ was found in comparison to EG2 (Xtract group, Table 2). The bacterial counts in caecum were lower than in faeces and no significant inhibitory effect was noted there.

In caecum of rabbits in EG1 (21 days after sage extract administration) higher value of lactic acid (LA) was noted $(0.060 \mathrm{~g} / 100 \mathrm{~g} \pm 0.009$, Table 3$)$ in comparison to CG1 $(0.042$ $\mathrm{g} / 100 \mathrm{~g} \pm 0.009)$, as well as higher value of butyric acid in EG1 $(0.139 \mathrm{mmol} / \mathrm{l} \pm 0.005)$ and EG2 (0.181 \pm 0.019$)$ was noted comparing to CG1 $(0.139 \pm 0.012)$; in EG2 siginificant $(p<0.05)$ amount of butyric acid was noted comparing to CG1 as well as CG2 $(p<0.001$, Table 3); values of acetic acid in EG1 $(0.458 \pm 0.049)$ and EG2 $(0.591 \pm 0.041)$ were also higher compared to CG2 $(0.418 \pm 0.115) 21$ days after sage extraction administration. The value of butyric acid achieved $0.155 \pm 0.023 \mathrm{mmol} / \mathrm{l}$ in EG1 and $0.159 \pm 0.003 \mathrm{mmol} / \mathrm{l}$ in 
Table 3 . The values of volatile fatty acids in the ceacum content

\begin{tabular}{|c|c|c|c|}
\hline & & day $21^{\mathrm{A}}$ & day $21^{\mathrm{B}}$ \\
\hline EG1 lactic acid & $\mathrm{g} / 100 \mathrm{~g}$ & $0.060 \pm 0.009^{\mathrm{a}}$ & $0.029 \pm 0.017$ \\
\hline acetic acid & $\mathrm{mmol} / \mathrm{l}$ & $0.458 \pm 0.049$ & $0.500 \pm 0.009$ \\
\hline propionic acid & $\mathrm{mmol} / \mathrm{l}$ & $0.028 \pm 0.004$ & $0.040 \pm 0.009$ \\
\hline butyric acid & $\mathrm{mmol} / \mathrm{l}$ & $0.139 \pm 0.005$ & $0.155 \pm 0.023$ \\
\hline EG2 lactic acid & $\mathrm{g} / 100 \mathrm{~g}$ & $0.042 \pm 0.009$ & $0.042 \pm 0.003$ \\
\hline acetic acid & $\mathrm{mmol} / \mathrm{l}$ & $0.591 \pm 0.041$ & $0.522 \pm 0.056$ \\
\hline propionic acid & $\mathrm{mmol} / \mathrm{l}$ & $0.038 \pm 0.002$ & $0.045 \pm 0.005$ \\
\hline butyric acid & $\mathrm{mmol} / \mathrm{l}$ & $0.180 \pm 0.019^{*}$ & $0.159 \pm 0.003$ \\
\hline CG1 lactic acid & $\mathrm{g} / 100 \mathrm{~g}$ & $0.048 \pm 0.007$ & $0.050 \pm 0.001$ \\
\hline acetic acid & $\mathrm{mmol} / 1$ & $0.529 \pm 0.045$ & $0.532 \pm 0.063$ \\
\hline propionic acid & $\mathrm{mmol} / \mathrm{l}$ & $0.034 \pm 0.011$ & $0.044 \pm 0.008$ \\
\hline butyric acid & $\mathrm{mmol} / \mathrm{l}$ & $0.135 \pm 0.012^{*}$ & $0.140 \pm 0.019$ \\
\hline CG2 lactic acid & $\mathrm{g} / 100 \mathrm{~g}$ & $0.041 \pm 0.005$ & $0.044 \pm 0.005$ \\
\hline acetic acid & $\mathrm{mmol} / 1$ & $0.418 \pm 0.115$ & $0.495 \pm 0.149$ \\
\hline propionic acid & $\mathrm{mmol} / \mathrm{l}$ & $0.028 \pm 0.003$ & $0.045 \pm 0.024$ \\
\hline butyric acid & $\mathrm{mmol} / \mathrm{l}$ & $0.110 \pm 0.011^{* *}$ & $0.124 \pm 0.050$ \\
\hline
\end{tabular}

EG1- experimental group (sage; $n=22$ ); EG2 - experimental group (Xtract; $n=22$ ); CG 1 control group (with coccidiostat Robenidin; $n=22$ ); CG 2 control group (coccidiostat free; $n=22$ ); 21 days of sage as well as Xtract administration, age of rabbits 56 days; ${ }^{\text {B }} 21$ days after of additive withdrawal, age of rabbits 77 days; ${ }^{\text {aStandard }}$ deviation $\left.\pm \mathrm{SD} ;{ }^{*} p<0.05, * * p<0.001\right)$

EG2 in comparison to CG1 $(0.140 \pm 0.019)$ and CG2 $(0.124 \pm 0.050 \mathrm{mmol} / \mathrm{l})$ after 21 days of sage extract cessation (the end of the experiment, age of rabbits 77 days). The values of propionic acid were not influenced.

The biochemical variables in blood samples checked in EG1 and EG2 were not influenced; they were comparable (Table 4). Concerning the GSH Px, lower values were found in EG1 compared to Xtract group (EG2).

Phagocytic activity (18\%, syn PA) was measured in EG1 compared to EG2 (PA 13\%) after 21 days of additive use (age of rabbits 56 days). At the end of the experiment ( 21 days after the additive was no more given to the animals, age of rabbits 77 days) $15 \%$ PA was detected in rabbits of EG1 in comparison to EG2 (17\%). Similar influence was noted by index of phagocytary activity: in EG1 (1.04 after 21 days; 0.4 after 21 days of cessation) compared to EG2 ( 0.8 after 21 days of addition; 1.5 after 21 days of cessation).

The reduction of Eimeria sp. oocysts was demonstrated in EG1 (sage extract group) after 7 days of sage application (age of rabbits 42 days, 217 OPG) comparing to CG2 (566 OPG), as well as after 21 days of sage extract application (age of rabbits 56 days, 600 OPG in EG1; 1306 OPG in CG1) and also after withdrawal of sage (in rabbits age 70 days, 84 OPG in EG1; 834 OPG in CG1).

The animals in both experimental groups had higher feed consumption and weight gain, lower mortality as compared to both control groups (CG1 and CG2) - Table 5. The feeding of additives did not have a negative influence on the health status and on growth performance of rabbits.

\section{Discussion}

The essential oils (extracts) are considered among the most important antimicrobial agents in plants having also antioxidant and anti-inflammatory activities. The analysis of 


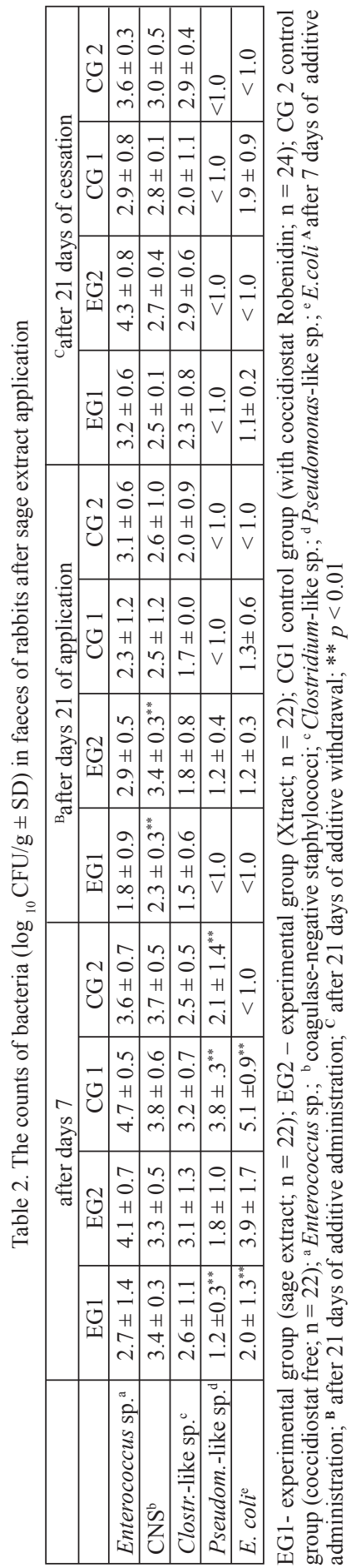

the essential oil composition of Salvia species indicates that borneol and cineol (eucalyptol) possess these properties (Delamare et al. 2007). The results of the antimicrobial activity of the essential oils, described by Delamare et al. (2007) reveal that the oils of Salvia officinalis inhibited the growth of Bacillus cereus, B. megatherium and $B$. subtilis. However, only slight effect was observed on E. coli and S. aureus. This discrepancy can be attributed to the composition of the essential oils used in each particular experiment.

Anticoccidial effects of green tea-based diets were evaluated in chickens by Seung et al. (2007). In the green tea-fed chickens significant reduction of faecal oocysts $(p<0.05)$ was noted compared to the E. maxima-infected group of chicken with the standard diet. The chamomile extract administration resulted in the reduction of Eimeria sp. oocysts in faeces of rabbits (Simonová et al. 2006). Neutrophil polymorphonuclear leukocytes (granulocytes) are responsible for the non-specific immune response and mainly for the share of phagocytosis intro-defence of the host to infectious and inflammatory actions (Escribano et al. 2005). Higher PA in EG2 can be explained by the combination of essential oils in Xtract (carvacrol from oregano, cinnamaldehyde from cinnamon and capsaicine from chilli peppers); it seems to have a longer immunomodulatory effect (Milos et al. 2000; Nofrarías et al. 2006). Concerning the values of VFA in caecum, Gidenne et al. (1998) reported that the VFA concentration changed slowly with the age of the rabbit. Administration of additives did not stimulate oxidative stress; lower values of GSH Px were noted in EG1 (sage group) compared to EG2 group.

In conclusion, the Salvia officinalis extract showed an antimicrobial effect on bacteria in the intestinal tract of rabbits (the significant reduction of Pseudomonas-like sp., $E$. coli, CNS) and anticoccidial effect; sage administration has a positive effect in rabbits by increasing the consumption and weight gain as phagocytic activity.

\section{Experimentálne podávanie šalvie v chove králikov}

Salvia sp. patrí do čel'ade Labiatae a je charakteristická antimikrobiálnym a protizápalovým účinkom. Ciel'om našej práce bolo zistit' možnosti alternatívneho užívania extraktu zo šalvie v ekosystéme králikov; ked’že v tomto prostredí a za týmto účelom šalvia využívaná doposial' nebola; ciel'om bolo testovat' antimikrobiálny a inhibičný účinok proti vybraným druhom baktérií v in vitro podmienkach ako aj $\mathrm{v}$ in vivo podmienkach pri sledovaní biochemických, zootechnických a imunologických ukazovatel'ov a tiež sledovat' vplyv aditív na výskyt oocýst Eimeria sp. v tráviacom trakte králikov v po- 
Table 4. Biochemical indicators comparing the sage group and Xtract group of rabbits

\begin{tabular}{|c|c|c|c|}
\hline Total proteins $\mathrm{g} / \mathrm{l}$ & sage & & Xtract \\
\hline $\begin{array}{l}\text { A - the start of the experiment } \\
\text { Age of rabbits } 35 \text { days }^{*}\end{array}$ & & $52.8 \pm 6.6$ & \\
\hline $\begin{array}{l}\text { B - after } 21 \text { days of additive } \\
\text { administration (age } 56 \text { days) }\end{array}$ & $63.7 \pm 5.9$ & & $66.4 \pm 6.2$ \\
\hline $\begin{array}{l}\mathrm{C} \text { - after } 21 \text { days of } \\
\text { additive withdrawal } \\
\text { (age of rabbits } 77 \text { days) }\end{array}$ & $66.5 \pm 11.5$ & & $65.8 \pm 6.1$ \\
\hline \multicolumn{4}{|l|}{ Total lipids g/l } \\
\hline $\mathrm{A}$ & & $6.7 \pm 2.1$ & \\
\hline $\mathrm{B}$ & $4.5 \pm 1.6$ & & $5.5 \pm 2.9$ \\
\hline $\mathrm{C}$ & $3.5 \pm 1.3$ & & $3.6 \pm 1.3$ \\
\hline \multicolumn{4}{|l|}{ Cholesterol mmo/l } \\
\hline $\mathrm{A}$ & & $3.7 \pm 2.7$ & \\
\hline $\mathrm{B}$ & $2.2 \pm 0.4$ & & $2.2 \pm 0.5$ \\
\hline $\mathrm{C}$ & $0.9 \pm 0.4$ & & $1.2 \pm 0.4$ \\
\hline \multicolumn{4}{|l|}{ Glucose $\mathrm{mmo} / \mathrm{l}$} \\
\hline $\mathrm{A}$ & & $6.8 \pm 1.1$ & \\
\hline $\mathrm{B}$ & $6.0 \pm 1.1$ & & $6.2 \pm 1.2$ \\
\hline $\mathrm{C}$ & $6.7 \pm 0.7$ & & $7.2 \pm 1.5$ \\
\hline \multicolumn{4}{|l|}{ Calcium mmol/ } \\
\hline $\mathrm{A}$ & & $3.0 \pm 0.7$ & \\
\hline $\mathrm{B}$ & $3.3 \pm 0.2$ & & $3.2 \pm 0.1$ \\
\hline $\mathrm{C}$ & $3.1 \pm 0.3$ & & $3.2 \pm 0.1$ \\
\hline \multicolumn{4}{|l|}{ ALT $\mu \mathrm{katl} / 1^{1}$} \\
\hline $\mathrm{A}$ & & $0.4 \pm 0.1$ & \\
\hline $\mathrm{B}$ & $0.13 \pm 0.03$ & & $0.09 \pm 0.03$ \\
\hline $\mathrm{C}$ & $0.15 \pm 0.03$ & & $0.09 \pm 0.06$ \\
\hline \multicolumn{4}{|l|}{ GSH Px (U/gHb) } \\
\hline $\mathrm{A}$ & & $140.1 \pm 36.4$ & \\
\hline B & $233.5 \pm 52.7$ & & $245.8 \pm 94.7$ \\
\hline $\mathrm{C}$ & $275.5 \pm 114.8$ & & $267.1 \pm 101.9$ \\
\hline
\end{tabular}

"background sample; ${ }^{1}$ alaninaminotransferase;

Table 5. Zootechnical variables during the whole experiment

\begin{tabular}{|l|c|c|c|c|c|}
\hline & & Sage & Xtract & CG 1 & CG 2 \\
\hline Feed consumption & $\mathrm{kg}$ & 112.56 & 116.00 & 107.85 & 103.82 \\
\hline Weight gain & $\mathrm{kg}$ & 32.12 & 34.77 & 29.69 & 30.72 \\
\hline Feed conversion & $\mathrm{kg} / \mathrm{kg}$ & 3.50 & 3.34 & 3.63 & 3.38 \\
\hline Mortality & $\mathrm{piece}$ & 4 & 5 & 5 & 6 \\
\hline
\end{tabular}

CG 1 control group (coccidiostat-free); CG 2 control group (with coccidiostat Robenidin)

Feed consumption and weight gain are calculated the whole group of animals involving.

rovnaní s komerčne používaným prípravkom Xtract. Výsledky in vitro testov potvrdili antimikrobiálny účinok extraktu šalvie. Za in vivo podmienok bola v experimentálnej skupine EG1 (podávanie šalvie) zaznamenaná redukcia Pseudomonas-like sp. $(p<0,01)$ a $E$. coli $(p<0,01)$ na 7 . deň po podávaní extraktu šalvie v porovnaní s kontrolnou skupinou s robenidínom (CG2). Redukované boli tiež počty koaguláza-negatívnych stafylokokov $(p<0,01)$ v skupine EG1 v porovnaní s experimentálnou skupinou EG2 ( skupina s Xtrac- 
tom) na 21. deň podávania aditív. V céku králikov v skupine EG1 boli zaznamenané vyššie hodnoty kyseliny mliečnej, octovej, maslovej. Hodnoty kyseliny propiónovej neboli ovplyvnené. Rovnako neboli ovplyvnené ani biochemické parametre; avšak hodnoty enzýmu glutationperoxidáza boli nižšie v skupine EG1. Vyššia fagocytárna aktivita (18\%) bola dosiahnutá v skupine EG1 než v skupine EG2 (13\%) na 21. deň po podávaní aditív. Na 7. deň bola zistená i redukcia oocýst Eimeria sp. v skupine EG1 v porovnaní s kontrolnou skupinou CG2 (217 OPG-566OPG). Zvieratá v skupine EG1 mali vyššiu spotrebu krmiva a konverziu krmiva ako aj vyššie hmotnostné prírastky v porovnaní so skupinou CG2. Ani šalvia ani Xtract nemali negatívny vplyv na zdravotný status králikov.

\section{Acknowledgement}

This work was supported by the Slovak Scientific Agency VEGA (project 2/0008/08). The authors would like to thank Mrs. M. Bodnárová for her excellent technical assistance, Dr. Rastislav Jurč́k from Slovak Centre of Agricultural Research in Nitra and Dr. Jana Poráčová from Department of Biology, University in Prešov for the co-operation in this experiment.

\section{References}

ALARCORN-AQUILAR FJ, ROMAN-RAMOS R, FLORES-SAENZ JL, AQUIRRE-GARCIA F 2002: Investigation on the hypoglycemic effects of extracts of four Mexican medicinal plants in normal and alloxandiabetic mice. Phytother Res 16: 383-386

BARICEVIC D, SOSA S, DELLA LOGGIA R, TUBARO A, SIMONOVSKA B, KRASNA A, ZUPANCIC A 2001: The biological/pharmacological activity of the Salvia officinalis L. leaves: the relevance of ursolic acid. J Ethnopharmacol 75: 125-132

BASGEL S, ERDEMOGLU SB 2006: Determination of mineral and trace elements in some medicinal herbs and their infusions consumed in Turkey. Sci Total Environ 359: 82-89

CAPEK P, HRÍBALOVÁ V, ŠVANDOVÁ E, EBRINGEROVÁ A, SASINKOVÁ V, MASAROVÁ J 2003: Characterization of immunomodulatory polysaccharides from Salvia officinalis L. Int J Biol Macromol 33: 113-119

DELAMARE APL, MOSCHEN-PISTORELLO IT, ATTI-SERAFINI LAL, ECHEVERRIGARAY S 2007: Antibacterial activity of the essential oils of Salvia officinalis L. and Salvia triloba L. cultivated in South Brazil. Food Chem 100: 603-608

DE VUYST L, CALLEWAERT R, POT B 1996: Characterization and activity of Lactobacillus amylovorus DCE471 and large scale isolation of its bacteriocin amylovorin L471. System J Appl Microbiol 19: 9-20

ESCRIBANO BM, CASTEJÓN FM, VIVO R, AGÜERA S, AGÜERA EI, RUBIO MD 005: Nonspecific immune response of peripheral blood neutrophils in two horse breeds (Anglo-Arabian and Spanish-Arabian): response to exercise. Compl Immunol Microbiol Infect Dis 28: 145-154

FICHI G, FLAMINI G, ZARALLI LJ, PERRUCCI S 2007: Efficacy of an essential oil of Cinnamomum zeylanicum against Psoroptes cuniculi. Phytomedicine 14: 227-231

GALI-MUHTASIB H, HILAN C, KHATER C 2000: Traditional uses of Salvia libanotica (East Mediterranean sage) and the effects of its essential oils. J Ethnopharmacol 71: 513-520

GIDENNE T, CARABANO C, GARCIA J, DE BLAS C 1998: Fibre digestion. In: DE BLAS and WISEMAN J (Eds): The nutrition of the rabbit. CABI, Wallingford, pp. 69-88. HRUBIŠKO M 1981: Test of phagocytosis of blood (In Slovak). Haematology and Transfusiology. Osveta, Martin, p. 19.

KARAKAYA S, EL SN 1999: Quercetin, luteolin, apigenin and kaempferol contents of somefoods. Food Chem 66: $289-292$

LIMA CF, ANDRADE PB, SEABRA RM, FERNANDES-FEREIRA M, PEREIRA-WILSON C 2005: The drinking of a Salvia officinalis infusion improves liver antioxidant status in mice and rats. J Ethnopharmacol 97: 383-389

MARCIN A, LAUKOVÁ A, MATI R 2006: Comparison of the effects of Enterococcus faecium and aromatic oils from sage and oregano on growth performance and diarrhoeal diseases of weaned pigs. Biologia 61: 789-795

MILOS M, MASTELIC J, JERKOVIC I 2000: Chemical composition and antioxidant effect of glycosidically bound volatile compounds from oregano (Origanum vulgare L. spp. hirtum). Food Chem 71: 79-83

NOFRARÍAS M, MANZANILLA EG, PUJOLS J, GIBERT X, MAJÓ N, SEGALÉS J, GASA J 2006: Effects of spray-dried porcine plasma and plant extracts on intestinal morphology and on leukocyte cell subsets of weaned pigs. J Anim Sci 84: 2735-2742

PAGLIA DE, VALENTINE WN 1967: Studies on the quantitative and qualitative characterization of erythrocyte gluthatione peroxidase. J Lab Clin Med 70: 158-169

SEUNG IJ, MOO-HYUNG J, HYUN SL, RAMI AD, IL-KEUN K, SUK K, WONGI M 2007: Anticoccidial effect of green tea-based diets against Eimeria maxima. Vet Parasitol 144: 172-175

SIMONOVĂ M, STROMPFOVÃ V, MARCIŇÁKOVÁ M, HAVIAROVÁ M, FAIX Š, LAUKOVÁ A, VASILKOVÁ Z, ŠALAMON I 2006: Chamomile essential oil and its experimental application in rabbits. 
In: Proceedings of International symposium on chamomile research, development and production. Prešov, pp. 122.

SZABÓOVÁ R, CHRASTINOVÁ L', HAVIAROVÁ M, SIMONOVÁ M, STROMPFOVÁ V, FAIX Š, VASILKOVÁ Z, PLACHÁ I, LAUKOVÁ A, RAFAY J, PORÁČOVÁ J 2006: Phytoaditives in rabbits breeding. Days of Nutrition and Veterinary Dietetics VII Košice, Slovakia, 13.-14. 9. 2006

TEPE B, SOKMEN M, AKPULAT HA, SOKMEN A 2006: Screening of the antioxidant potentials of six Salvia species from Turkey. Food Chem 95: 200-204

WANG M, LI J, RANGARAJAN M, SHAO Y, LAVOIE EJ, HUANG TC, HO CT 1998: Antioxidative phenolic compounds from sage (Salvia officinalis). J Agric Food Chem 46: 4869-4873

XU G, SALEN G, TINT GS, BATTA AK, SHEFER S 1999: Campestanol (24-methyl-5 $\alpha$-cholestan-3ß-ol) absorption and distribution in New Zealand white rabbits: Effect of dietary sitostanol. Metab Clin Exp 48: 363-368 